\title{
Practice training and analysis of Human geography \& Urban-Rural Planning professional :A case study of Guangzhou University
} Yanyan LIU ${ }^{a}$, Yinjie HE ${ }^{b}$, Dafang WU'c Meizhen LIN ${ }^{d}$, and Muzhuang YANG ${ }^{e}$

Institute of Land Resources and Urban-Rural Planning, College of Geographical Sciences, Guangzhou University, Guangzhou 510006, China;

aAuthor email: liuyy@gzhu.edu.cn, ${ }^{\mathrm{b}}$ email: Terrence17@163.com, ${ }^{\mathrm{C}}$ Corresponding author email:wudaf2004@163.com, 'email: Lmzh888@163.com, eemail: yangmz@21cn.net

Keywords: Human geography \& urban - rural planning; Curriculum system; Professional construction.

Abstract. The purpose of this article is through the human geography and planning in urban and rural areas of Guangzhou university for example to explore the discipline of personnel training and curriculum reform, So this article has certain reference and guidance. This article firstly analyzes foreign urban planning discipline development and changes, then according to China's national conditions, expounds the National Ministry of Education in September 2012, the resource environment and urban and rural planning management professional cancelled, adjusted for two new professional natural geography and resources environment and human geography and planning in urban and rural areas. Secondly human geography and planning in urban and rural areas in Guangzhou university curriculum system as an example to explore its advantages and disadvantages. Finally summed up the human geography and planning in urban and rural areas of Guangzhou university how to use a flexible mechanism, the vivid teaching method, based on the advantage of the platform of the Guangzhou international metropolis to form their own professional brand characteristics.

\section{Introduction}

Urban planning professional education in Europe and the United States and other western developed countries has nearly a century. According to it, the world's first major is urban planning in 1909 by the British were the first to set up at the university of Liverpoo ${ }^{[1]}$. Later, western urban planning is no longer a simple space design, but includes the political, economic, social and ecological aspects of a complex of content, with the change of The Times. Theory, key work content, method and means of western urban planning subject evolving. The western developed countries, such as Germany, France, the United States are generally emphasizes interdisciplinary foundation in the urban planning education, because of the urban system is more and more complex, a single subject knowledge system can't support such a complex system. A lot of work which Like Mr Diaz's Human settlement, and Kevin lynch's City image, Alexander's City is not a tree, Jane's Die of big American cities and so on represented by the city's cultural, historical, social, time, meaning, spatial behavior and psychological theories, such as content, greatly enrich the urban planning discipline of humanities and social science related content ${ }^{[2]}$. In addition, developed countries and regions of the city planning professional education has experienced from engineering to architecture, the geography, the environmental science, again the process of social science, with the development of social economy, the demand of the urban construction in constant adjustment ${ }^{[3-4]}$. 
China is in the intermediate stage of urbanization. The Ministry of Education in order to adapt to the optimization and upgrading of China's industry, strengthen the research on the urban and rural integration process accelerated, the social sustainable development and social demand for the planning and management of the geography background of professional talents growing. the city planning major adjustment for level 1 subject, in the 2011. The academic degrees committee of the state council said planning is an ancient and young subject in notice. Urban planning discipline development is facing new opportunities and challenges, many scholars in China have realized the establishing and perfecting system of urban planning theory system of urgency ${ }^{[5]}$. So, Issued by the Ministry of education on September 2012 of The undergraduate course of common colleges and universities professional directory and Professional set of undergraduate course of common colleges and universities management regulations, Stipulated in geography science 0705, the resources environment and urban-rural planning management professional adjusted for two new professional natural geography and resources and environment 070502 and human geography and urban planning 070503. Already has in the past 4 years now. Runs the professional universities, normal universities, geological mining kind schools, agriculture and forestry colleges, building engineering colleges and about 150 universities in China are of its own original professional teaching mode has carried on the corresponding adjustment and explore. But is now generally exist the following problems:1, contents did not change, it is divided into two major, but still some teachers to teach. 2, the structure of the curriculum system on inelastic, poor selectivity. Students learning content a lot but not deep, they are confused about professional direction. 3, cramming education class; Heavy commonness, light personality; Heavy theory, light practice. 4, the obsolete teaching content, aging, and reality seriously derailed. 5, Practical teaching link is relatively weak, professional teachers' shortage, the quality is not high, part of the course without teachers or relatively weak. For now, most students can master the basic theory of city planning, But in actual operation are lacking, employment competitiveness not good as engineering of city planning students 082802. Under the background of national emphasis on practice teaching in colleges and universities, students of under the background of geography research field should be more specific, more professional pertinence, practical teaching demand higher ${ }^{[6]}$. So this article was to explore the geographical background of the urban and rural planning teaching system to improve and develop the students' practical ability is of great significance.

\section{The positioning of fostering talents}

First of all, we have to clear the talent training goal: teachers are not only teaching in order to complete the task, In the same way, the students is not only learning in order to complete the task, More not to study for a graduate diploma. Academician of Xie(2016) lecture which theme is to face the question of Qian Xuesen -- about the thinking of training high level talents in universities and colleges said: Reveals the status quo about the question of Qian Xuesen all over the world exist in different degrees, the essence of which is urgently needed a master talent, and some unreasonable education means, measures and evaluation system is as a deterrent to cultivation of talents in colleges and universities. Create a good academic ecological environment, training high level talents, what should be the focus. It generally reflect, Class of urban and rural planning of science specialized student if you want to further study are relatively simple, because most colleges and universities set up the professional master's and doctoral degree. Class of urban and rural planning of engineering specialized student is focused on cultivate professional requirements. But the 
students'under the background of science employment choice is less, students choose more jobs in the government department, outside the company only like real estate companies and mapping of surveying and mapping company and so on recruit this professional students, national civil service exam no advantage in terms of professional.

Famous theorists of city planning in the United States Lewis Mumford (1934) once put forward: real impact of urban planning is a profound political and economic transformation. At present, the Chinese economic development the new normal. The economy of China is from rapid growth to high-speed growth, development mode is growing from extensive type to intensive growth type. So ordinary institutions of higher learning should be on the graduate employment market positioning is clear, local university talents training target and pattern positioning accurately, Personnel training mode should not be "A mold carved inside" of the bad situation, but can meet the needs of professional diversification.

Human geography and urban and rural planning of Guangzhou university aim to have their characteristics, Advocate the discipline integration, advocacy of "professional wide and narrow direction" and the integration of knowledge and ability structure. It response social occupational demand ,based on real estate, regional logistics, has its distinctive features, objective to cultivate students to work in the related government departments, enterprises and institutions to Engaged in the regional development and construction, urban and rural planning and management, real estate feasibility studies, market research and consulting project planning management and regional logistics planning and management. In the direction of real estate, Let the students learn basic principle on the basis of geographical science, mainly study the basic theories of human geography and urban and rural planning and the basic knowledge, accept the urban and rural development and real estate management skills training, method and way to master the application of geographic information technology, and through the necessary practice exercise, has the strong ability of geographic information technology, solid professional disciplines knowledge and better ability to apply knowledge. Let the students can participate in urban and rural planning and construction work, and can carry out real estate market research, project planning and advisory management, and other related work. Regional logistics direction, Let students learn basic principle on the basis of geographical science, focuses on studying logistics planning and design of basic theory and basic knowledge, accept the analysis of regional logistics, warehousing, transportation planning optimization, distribution management skills training, the method and way to master the application of geographic information technology, and through the necessary practice exercise, has the strong ability of geographic information technology, solid professional disciplines knowledge and better ability to apply knowledge. Let the students to carry out the logistics survey, planning and management; Logistics market analysis, project planning and consulting related work.

\section{Curriculum system}

\section{Basic curriculum system}

Human geography and planning in urban and rural areas is a comprehensive cross subject, the goal is to cultivate high-quality professional talents. students must be introduction to lay a solid theoretical foundation, to form professional thinking, these for work or test the graduate student is has the certain help. Guangzhou university the basis of the course system of human geography and planning in urban and rural areas as shown in table 1. 
Table 1. Basic subject system

\begin{tabular}{|c|c|}
\hline Attribute & Curriculum system \\
\hline $\begin{array}{l}\text { Public foundation } \\
\text { platform courses }\end{array}$ & English, politics, sports, etc \\
\hline $\begin{array}{l}\text { Discipline } \\
\text { course }\end{array}$ & $\begin{array}{l}\text { Introduction to professional, cartography, advanced mathematics III, } \\
\text { geographic information system(GIS), database technology and application } \\
\text { II, comprehensive natural geography, human geography, etc }\end{array}$ \\
\hline $\begin{array}{l}\text { Professional required } \\
\text { course }\end{array}$ & $\begin{array}{l}\text { Physical geography, introduction of environment, urban geography, urban } \\
\text { planning theory, urban planning experiments, economic geography, } \\
\text { regional analysis and planning, etc }\end{array}$ \\
\hline $\begin{array}{l}\text { Courses } \\
\text { modules }\end{array}$ & $\begin{array}{l}\text { VB language program design, the theory of probability and mathematical } \\
\text { statistics, linear algebra I, geographic modeling, GIS software and } \\
\text { application, principles of management, western economics, marketing, } \\
\text { management, psychology, business, geography, statistics software } \\
\text { application, principle and the application of remote sensing, subject } \\
\text { research methods, etc }\end{array}$ \\
\hline
\end{tabular}

Basic curriculum goal is to develop the students' ability of basic practice. Natural geography, human geography and geographic information system (GIS) is an important branch of the discipline of geography science three disciplines, and cartography is unique geographical subject expression tool, remote sensing is an important means of geographic information. Through the practice of the five course construction of human geography and urban and rural planning professional basic practical ability, build with identification of geographical phenomenon characteristics and master the basic geographical information expression technology practice ability.

\section{Module teaching system}

Based on market needs, clear goals of talents cultivation, advocacy of "professional wide and narrow direction", it is characteristics of Guangzhou university. Real estate and logistics is a main direction in the area, in the teaching system of template to teaching, emphasize professional, practical application of the principle. There is a specific direction, to avoid the learn it without problems, make the students study more deeper, Let not further study of students can better with actual social practice. As shown in table 2. 
Tab.2 Module teaching system

\begin{tabular}{ll}
\hline module & Curriculum system \\
\hline Real estate module & Construction drawing, computer-aided design, real estate development and \\
& management, land and real estate law, cadastral and real estate survey, real \\
& estate economics, land management, real estate management, real estate \\
& investment analysis, building architecture, real estate appraisal and property \\
& management principle, commercial property management, land and real \\
& estate management information system, engineering budget, property \\
& management facilities and equipment, living environment and landscape \\
& design, real estate management comprehensive experiment, the real estate \\
& market research, professional English, urban economics, land economics, real \\
& estate finance, etc \\
Regional logistics & Modern logistics, enterprise logistics management, warehousing and \\
module & distribution, logistics, transportation management, operational research, \\
& logistics information technology, international trade, logistics technology and \\
& equipment, positioning and navigation technology, supply chain \\
& management, logistics planning principle, simulation technology, the \\
& logistics enterprise financial management, international logistics, logistics \\
& planning and process design experiment, analysis of e-commerce and the \\
& Internet, the logistics geography, third party logistics, reverse logistics \\
& management, logistics system analysis, system engineering, logistics strategy \\
& management, economic law, logistics professional logistics English, etc
\end{tabular}

The curriculum system is mainly to cultivate the students' comprehensive practical ability. For real estate direction and regional logistics application direction, should be on the basis of the basic practical ability, using statistical software, based on geographic modeling, CAD and simulation practice, strengthen the two professional direction of the students' ability of quantitative analysis and computer simulation. And through the professional practice and graduation practice methods theory and technology are used in urban and rural planning and development, real estate planning and management, as well as the regional logistics planning and management, supply chain optimization problems.

\section{Practical tutorial system}

Practice tutorial is human geography and urban and rural planning undergraduate stage essential study part, In order to out of the boring teaching of "cramming education", make students more solid knowledge, raises student's beginning ability, team consciousness and innovation spirit, humanistic geography and urban planning of Guangzhou university always pay attention to combining theory with practice. Not only opened a colourful simulation practice, innovation projects, but also with multiple outside companies have good relations of cooperation. Teachers encourage students to the school's practice base practice, at the same time also will be sent to guide teachers to deal with the difficulties students work, lets the student with better social docking, also let the students know their own ability that still need to improve. Guangzhou university has own characteristic in practice tutorial, as shown in table 3. 
Tab.3 Practical tutorial system of human geography \& urban - rural planning

\begin{tabular}{|c|c|c|}
\hline Course category & Course name & Ability training \\
\hline $\begin{array}{l}\text { Discipline basic } \\
\text { course }\end{array}$ & $\begin{array}{l}\text { Cartography, geographic } \\
\text { information system, database } \\
\text { technology and application II }\end{array}$ & Experimental operation ability \\
\hline $\begin{array}{l}\text { Professional } \\
\text { required course }\end{array}$ & Urban planning experiment & Experimental operation ability \\
\hline $\begin{array}{l}\text { Concentrated } \\
\text { practice teaching }\end{array}$ & $\begin{array}{l}\text { Physical geography practice, urban } \\
\text { planning practice, human } \\
\text { geography practice, regional } \\
\text { comprehensive practice, } \\
\text { graduation practice and graduation } \\
\text { thesis }\end{array}$ & $\begin{array}{l}\text { Comprehensive analysis and } \\
\text { planning ability }\end{array}$ \\
\hline Real estate module & $\begin{array}{l}\text { Computer aided design, cadastral } \\
\text { and properties measurement, real } \\
\text { estate management, real estate } \\
\text { market research, the } \\
\text { comprehensive experiment and } \\
\text { real practice }\end{array}$ & Investigation and planning ability \\
\hline $\begin{array}{l}\text { Regional logistics } \\
\text { module }\end{array}$ & $\begin{array}{l}\text { Operations research, positioning } \\
\text { and navigation technology, } \\
\text { simulation technology, logistics, } \\
\text { supply chain management, } \\
\text { planning and process design } \\
\text { experiment, modern logistics } \\
\text { practice }\end{array}$ & Actual application ability \\
\hline
\end{tabular}

Practice of the tutorial goal is to develop practice innovation ability. Based on the perspective of geography, plore the geography in the urban and rural planning and construction, real estate planning management, regional logistics planning management in the field of new applications by apply geographic information technology.

\section{The teaching method of exploration and trial}

\section{To optimize the graduation practice time scheme}

Students in senior mostly choose to take examination of civil servants or the graduate, due to the particularity of this major. Then four long practice time will become baggage for exam and have the pressure of the graduation thesis. So the students can't concentrate on work, learn the truth thing. At the same time, institutions or companies are unlikely to teach students some technical thing considering the classmate in temporary jobs. So the school can put graduation practice time allocation by the end of each semester, let the students free combination of time, Each practice team assigned a practice guidance teachers, So that students can study in practice - study - practice - 
study in the process of "rolling" feel the value of knowledge and their disadvantage. Students don't have to stay in school learning they can be as early to work at the same time also shortened the textbook theory and social distance.

\section{Update of teaching method}

The teacher should change the teaching idea that teaching by the traditional "cramming" class and blunt PPT. Thousand times of exam content is no longer suitable for today's students. In the information age today, Students by many outside the temptation of society then shift in thinking. The past mode of education makes students feel boring, thinking it is better by self-study. it requires teachers to heuristic education, Such as in the classroom, with students together to solve a case, and let students bring questions to class, Guide the students to solve the problems about the case. This will make students more profound impression of nouns When appear new nouns in case and the teacher explained the noun. Instances show that This teaching method, effect is much better than before, Classroom atmosphere is also obvious active than before, students also can solve on the spot, Students' scores are significantly higher than before in the final test.

\section{Creation of the second classroom}

For a long time, many colleges and universities only emphasize students how to become a useful person to society, Ignore missing "people-oriented" concept of education and Student has their subjective initiative and value orientation. Teaching should understand respect students, Equally for each student performance, creative chances of success to them. Support various forms of students' academic research organizations, in the research and practice training to cultivate the students' cooperation ability, expression ability and comprehensive application ability of knowledge. Often invite other experts hold academic frontiers pulpit to inspire the student mind to rich knowledge. According to the characteristics of grade to organize speech, essay competition.

\section{The professional innovation in the information age}

The use of GIS tools for human geography and urban and rural planning has brought the revolutionary technology. On the one hand, the use of information technology to strengthen urban and rural planning, transportation planning, public health, wisdom, and the healthy city construction, city life space reconstruction and optimization, urban management and service, etc. On the other hand, the subjects also need to actively pay attention to climate change, environmental pollution, the spread of disease, vulnerable groups, global problems like terrorist activities. The needs of the older teachers to explore the new technology of "big data" method, jump out of the traditional framework, with an open view and attitude to hug the benefits of science and technology changes with each passing day. At the same time, the school hardware facilities to synchronize with company's equipment of the society as far as possible, to let the student takes pride in the school ${ }^{[7]}$.

\section{Conclusion}

According to China's national conditions combined with international advanced professional education concept is to improve the human geography and urban planning in our country education system effective way. Responsible attitude to combine the advanced ideas of western China's national conditions, inherit and develop excellent thinking part of our country: Humanistic spirit. 
The unity of people and the environment. Gradually form more suitable for China's current national conditions, more scientific and perfect discipline system. In addition, China's long-term feudal centralized rule caused urban and rural big gap, large agricultural population, the contradiction between population and resources and the pressure of the ecological environment degradation. These will make the future of China's urbanization process appear unique characteristics, its particularity is the human geography and planning in urban and rural must be faced.

Guangzhou university human geography and urban and rural planning should establish own characteristics. In terms of subject construction and talent cultivation, Schools should not blindly learning other famous school curriculum development. In the talent cultivation level should not be blindly compared with other university. Instead of focus on the limited resources, aim at the special demand of Guangzhou, in certain aspects of personnel system of knowledge structure and ability to break through, form their own characteristics and brand Guangzhou university. Under China promulgated the guidance of professional directory Guangzhou university set up specialized in real estate, regional logistics development in both directions. This can maintain a professional is relatively stable and can adapt to the social demand for talent.

Human geography and urban and rural planning as a new major, there are a lot of improvement on the training plan and target. many colleges and universities which open this professional according to their own situation also makes an attempt and explore actively. This article with Guangzhou university as an example explored the background of science of the human geography and urban and rural planning existing in the advantage and deficiency for the professional course setting. Firstly, combination of theory and practice, based on the advantage of Guangzhou international metropolis and demand, improve the students' practical application ability, to participate in social activities and teacher's project. Secondly, Optimize the curriculum, the inspection way, from set out actually and pay more attention to students' real needs rather than blindly imitate other professional. Thirdly, Ask the teacher to keep pace with The Times, understand the forefront of science, teach the subject the latest things to students, broaden students' horizons. Fourthly, Refinement of professional courses direction, take the student as the main body, let the student feel learning and useful, and employment is no longer confused about the future.

\section{Acknowledgements}

This work was financially supported by the National "Twelfth Five-Year" Plan for Science \& Technology Support(2013BAJ13B01), National Natural Science Foundation of China (41101078), Guangdong education department innovative projects(2014KTSCX090), Guangdong education scientific research "twelfth five-year" rules Row 2013 annual research project (2013JK134), the quality of undergraduate education and teaching reform project of Guangdong province "Real estate management" high-quality goods resource sharing class, The teaching quality and teaching reform project of Guangdong province (human geography and urban and rural planning and construction of professional teaching team, human geography and urban and rural planning professional comprehensive reform pilot, social demand oriented application geography BCA engineering personnel training mode and practice - A case study in natural geography and resources environment), Guangzhou university demonstration experiment project 2015 "geographic information system application in land use planning". 


\section{References}

[1] Tang z 1,2003. Constantly change in the urban planning education abroad urban planning. (in Chinese)

[2] Cui Y W, 2005. Applied talents training model in the major of urban planning[D]. Chongqing: Chongqing Universty, 1-81. (in Chinese)

[3] Dong J, 2010. Urban planning should higher education to become more professional: The French urban planning education system and related arguments. International Urban Planning.6:87-91.(in Chinese)

[4] Wei Y P, 2010. American planning education and basic teaching organization: We can use[C]. The National Conference on Urban Planning of Professional Teaching. Beijing: China Building Industry Press, 338-344. (in Chinese)

[5] Yao C, 2014. The main body of modern western urban planning theory and practice research[D]. Hangzhou: Zhejiang University, 1-61. (in Chinese)

[6] Zhu P J, Li Y, 2016. Human geography and urban and rural planning professional practice tutorial teaching satisfaction research: In case of planning and design of CAD course, Higher Science Education, 217(3):112-118. (in Chinese)

[7] Wu D F, Liu Y Y, Yao Y Y, et al., 2014. Domestic research progress analysis of land use planning. Land and Natural Resources Research, 5:27-31. (in Chinese) 